\title{
Environment-Based Education Integrated Islamic Values to Cultivate Environmental Literacy and Attitudes
}

\author{
Atik Rahmawati ${ }^{1,2}$, Kasmadi Imam Supardi ${ }^{2}$, Sri Mulyani ES ${ }^{3}$, Sri Haryani ${ }^{4}$ \\ ${ }^{1,3,4}$ Graduate School, Universitas Negeri Semarang, Indonesia \\ ${ }^{2}$ Program Studi Pendidikan Kimia-Fakultas Sains dan Teknologi, UIN Walisongo \\ Corresponding email: atik_rahmawati@walisongo.ac.id
}

\begin{abstract}
The development of science and technology that not observe to environmental balance has caused environmental change and become a global problem almost in all countries in the world. This phenomenon motivated environmental education to educate not only in the cognitive and psychomotor domain but also in the affective domain. These domains could be achieved through by problem-based learning with context socioscientific issue integrated Islamic values. The activity of problem-solving with context SSI strengthens student involvement comprehensively on environmental issues and how to solve the issues that it enhances students' understanding of environmental issues. Knowledge and Islamic values were believed to affect the pattern of thinking and could affect students' perceptions. The environmental sensitivity attitude was begun by perceptions of environmental sensitivity behaviour. The effectiveness of environmental educations' concept could strengthen environmental literacy and readiness to behave environmentally responsible.
\end{abstract}

Key word: environment-based education, Islamic values, environmental literacy, attitude.

\section{Introduction}

The rapid development of science and technology has become a substantive part of human life today and has touched of people's lives. However, due to the development has brought the impact of environmental quality decline. So, in order to face the environmental challenges on earth, there is a need to educate and inform the public about environmental issues. One of the communities 'and international governments' commitment to safeguarding the earth from pollution and destruction is through the implementation of Environmental Education, which is key to preparing communities with knowledge, skills, values, and attitudes of environmental concerns so as to actively participate in solving environmental problems (Leiserowitz, 2006). The development and guidance of environmental literacy become very important for environmental education programs.

The objectives for environmental education (EE) as defined by the 1977 Tbilisi Intergovernmental Conference on Environmental Education (Igbokwe, 2016). There are some defines of people who have environmentally responsible, they are the one who has (1) a sensitivity and awareness of the total environment and try to solve the problem [and/or issues], (2) a basic understanding of the environment and try to solve the problem [and/or issues], (3) feelings of concern to improve and protect of an environment, (4) skills for identifying to solve environmental problems [and/or issues], and (5) always participating at all levels in working toward resolution of environmental problems [and/or issues](Igbokwe, 2016).

Human behaviour based on environmental cares and environmental ethics can improve the quality of the environment (Castano (2008), Oktavian \& Maryani (2003)). Eco-friendly behaviour is stimulated by a true cognitive understanding of important environmental concepts related to environmental management. Understanding the concept becomes very important as a foundation concerning readiness to behave called environmental literacy (Fathil, 2015). The manifestation of the society that has environmental literacy is shown by the form of society that has the character of environmental care (Fathil, 2015).

Various research results show that the implementation of environmental education in schools has not been able to strengthen environmental literacy and readiness to behave. According to environmental education experts, some people have not or do not use their environmental awareness to behave in an environmentally responsible attitude (Hungerford \& Volk, 2013). Therefore, experts believe that there is a gap between the "cognitive and behavioural patterns" of humans. This shows that the educational process is not yet integrated, still partially separated among cognitive, affective, and psychomotor aspects. 
Education related to affective aspects are still limited to religious education, character education, which is separate from other fields of science. This brings implications to the dichotomous science paradigm. So it becomes very important to integrate science with religious values. There is a connection between the religious beliefs of scientists with the research and the discovery of science. The results show that religious beliefs influence scientists' research and their scientific discoveries (Lewis \& Leach, 2006).

The cultivation of character education through environmental education still encountered various weaknesses among them in the learning process is dominated on the content of knowledge that is not applicable to the students cannot build and understand the deep meaning of the nature of care and preserve the environment. Environmental education has not been linked to real issues and contains practical things from real life around the students. Referring to this, learning should provide students with experience to solve environmental problems that are now a global issue with constructive ideas, building environmental literacy behaving in a more environmentally responsible way.

Environmental issues are never separated from social problems that have had direct and indirect impacts on the survival of human life. Thus it becomes very important to problembased learning based on social issues.

Contextual learning socio-scientific issue (SSI) is a learning that aims to involve students in decision-making today's social issues with moral implications inherent in scientific contexts (Supardi, 2017). SSI is chosen to be a learning context because SSI can be used to make science learning more relevant to the student's daily life context, directing learning outcomes, enhancing argumentation dialogue, enhancing the ability to evaluate scientific information, and developing science literacy (L. Simonneaux \& J. Simonneaux, 2009; Mansour, 2015; Marks \& Eilks, 2009; Mulyana, 2009). In this paper will examine from various literature-based learning environment through Problem-Based Learning (PBL) contextualized SSI integrated Islamic values to increase literacy and attitudes of environmental care.

\section{Results and Discussion}

\subsection{The Integrated of Science and Islamic Values}

Science studies the nature of matter based on the laws of nature (sunnatullah). Sunnatullah applies scientifically, objectively, and does not change over time (Haryani, 2012). The powers of natural law are expressed in the Qur'an of Alfurqaan verse 2:

2. He to Whom belongs the dominion of the heavens and the earth: no son has He begotten nor has He a partner in His dominion: it is $\mathrm{He}$ Who created all things and ordered them in due proportions".

The existence of integration of Islamic values can be understood from various word of Allah SWT, among them is Q.S Aliimran [3]: 190-191:

190. Indeed, in the creation of the heavens and the earth and the alternation of the night and the day are signs for those of understanding.

191. Who remember Allah while standing or sitting or [lying] on their sides and give thought to the creation of the heavens and the earth, [saying], "Our Lord, You did not create this aimlessly; exalted are You [above such a thing]; then protect us from the punishment of the Fire.

The verse shows that the creation of the heavens and the earth and the alternations of day and night concerns the dimensions of mind and faith. The sense dimension is represented by the word "thinking", a word representing a deep thought activity accompanied by observation, analysis, and inference. This thinking activity is accompanied by an awareness of the regularity that comes from the Creator.

Internalizing the Islamic values in the learning process in principle makes all the attributes of God as a reference in understanding the material and the process of acquiring knowledge. According to Rochman (2010), a process of learning science is said to contain Islamic values if the learning phase starts from the step of understanding the order of His creation, understanding beauty, and relating order and beauty with the awareness of His Majesty (Khanafiyah \& Yulianti, 2013). 


\subsection{Islam and the Environment in an Educational Perspective}

In Quran, there are many verses that speak about the obligation to maintain and restrict of ruining the environment. The universe and its contents are created by Allah for humans, so humans occupy the most important position in the environment to protect the environment from damage and ensure its sustainability.

Quran provides many incentives to maintain and care for nature and the environment. The mission of Islam basically includes maintaining the attitude of the universe. As the Word of God in Qur'an Surah al-Anbiya, verse 107: "And we have not sent you except for (a) mercy for all creatures". Have mercy on nature is an integral part of the implementation of the teachings of Islam as a whole (Khanafiyah \& Yulianti, 2013).

The Human task as a caliph demands interaction between fellow human beings and human with nature. The interaction is harmonious in accordance with the instructions of the Divine instructions contained in His revelation. This is the basic principle which is the basis of the interaction between fellow human beings and the surrounding environment and harmonious relationship that is also the goal of all religious ethics (Ozsoy, Ertepinar, Saglam, 2012).

Humans have an obligation to protect the environment for the sustainability of life, not only for humans but for all other living beings. Human action in excessive use of natural resources which ignores basic maintenance and conservation resulting in environmental degradation and damage is prohibited (haram) and will be punished. Instead man capability of carrying out the maintenance and conservation of nature well, there is a reward for him from Allah SWT. As in the Word of Allah Q.S Ar Rum verse 41: The mischief has appeared in the land and sea, because of the evils earned by the hands of men, so that Hemay make them taste some of their doings, that haply they may turn back.

Exemplary to the environment is also exemplified by the Messenger of Allah. He laid down the general principle of preserving the environment in the form of a ban on destruction on Earth, such as prohibiting environmental pollution, "Abstain from three cursed behaviours, dispose of waste at water sources, by the wayside, and under the shade of trees." (HR Abu Daud, Ahmad and Ibn Majah). Likewise in terms of energy savings. He criticized Sa'ad for performing ablution (and much use of water), despite being in a flowing river.

There is some educational value that can be taken when humans interact with the environment. The principles that may be holding and guiding the human behaviour in confronting the nature, good behaviour among humans regarding nature. Educational values in are: (1) respect for Nature; (2) moral responsibility for nature; (3) Principle of Love and Concern for the Environment (Caring for Nature); (4) The principle of humankind (Khanafiyah \& Yulianti, 2013).

There are four educative methods in teaching the value of the Qur'an, besides iqra, according to An Nahlawi, are : amtsal method (analogy), hiwar method (dialog), targhib and tarhib method (encouragement and warning).

\section{3roblem-Based Learning Context SSI for \\ Growing Literacy and Environmental Care}

Problem-based learning is a learning approach that uses the problem as a starting point for learning. This lesson advises the student to seek or determine relevant sources of knowledge. Thus, this learning challenges the student to construct knowledge independently, with teacher/lecturer guidance. The role of the teacher as a facilitator helps the student at the outset, accompanies the student when the student is having difficulty. This is in keeping with the constructivism view supported by Ausubel, Bruner, and Vygotsky's learning theories (Ozsoy, Ertepinar, Saglam, 2012).

The problem-based learning process supports active, collaborative, student-centred learning, developing problem-solving skills, self-study capabilities as a means of facing complex challenges ahead. This learning can develop substantial basics of knowledge with the problem of an ill-structured problems active solver. Through this situation, students gain an opportunity how to learn (learn how to learn).

Problem-based learning will be more meaningful if the teaching uses a context. The context that can be used is the socio-scientific issue (SSI). Contextual learning SSI is a learning approach that examines facts, phenomena, or events based on social issues related to the existing science in society. This issue is controversial in nature but has additional elements that require a level of moral or ethical reasoning in decision-making in resolving those issues. (Zeidler and Nichols, 2009: 49) 
The contextual issues discussed are very motivating to the students and this emphasizes the importance of science learning in the classroom that deals with socioscientific issues. Contextual, epistemological, emotional, and socio-cultural relationships influence the student's argumentation process on controversial issues (Siswanto, 2008; Marks \& Eilks, 2009). Contextual learning SSI can enhance the understanding of science concepts and the relationship between science and the environment (Sadler \& Donnely, 2006).

The initial concept of environmental literacy was defined by Roth in 1968. Roth defines a person who has environmental literacy as someone who has a basic skill, understanding, and feelings for human-environmental relationships (Leiserowitz, 2006). A person with environmental literacy must understand the interconnectedness of the natural and social systems, the unity of man with nature, how technology influences environmental issues decisions and learning about the environment as a lifelong effort. Igbokwe (2016) states the major components of environmental literacy are knowledge, attitude, motivation, cognitive ability, skills, and willingness to act on the environment (Milfont \& Duckitt, 2010). The status of one's environmental literacy can be measured based on the criteria of environmental literacy components: Knowledge, cognitive skill, attitude and environmentally responsible behaviour (Behaviour). (NAAE)

Environmental care is a crucial construct in environmental psychology. Milfont \& Duckitt (2010) defines environmental care as a psychological tendency expressed by evaluating the environment with multiple levels of both favourites and disfavours. According to Milfont \& Duckitt, (2010), there are 12 levels of environmental cares: (1) Enjoyment of nature, (2) Support for interventionist conservation policies, (3) Environmental movement activism, (4) Conservation motivated by anthropocentric concern, (5) (Confidence in science and technology, (6) Environmental threat, (7) Altering nature, (8) Personal Conservation behaviour, (9) Human dominance over nature, (10) Human utilization of nature, (11) Ecocentric concern, and (12) Support for population growth policies) (Albe, 2008).

The integration of environmental related materials can foster an attitude of environmental concern. Application of Problem Based Instruction learning model in Environmental
Physics course shows an increase of environmental awareness attitude and student ability in solving problems.

PBL contextualized SSI has the potential to strengthen the readiness of behaving ecofriendly because it demands students actively in developing their creativity, stimulates the thinking process by triggering the activation of all the senses, fully involved in the learning process so as to gain deeper knowledge and improve the students' ability in mastering the learning materials. Knowledge gained through education can affect students' perceptions. Perception will ultimately affect how students behave and behave. Environmental caring begins with perceptions of environmental caring behaviour. If the perception is positive then the attitude shown is also positive (Fathil, 2015).

\section{Conclusion}

The activity of problem-solving with context SSI strengthens student involvement comprehensively on environmental issues and how to solve the issues that it enhances students' understanding of environmental issues. Knowledge and Islamic values were believed to affect the pattern of thinking and could affect students' perceptions. The environmental sensitivity attitude was begun by perceptions of environmental sensitivity behavior. The effectiveness of environmental educations' concept could strengthen environmental literacy and readiness to behave environmentally responsible

\section{References}

A. Leiserowitz. (2006). Climatic Change 77: pp.45-72.

B. A. Igbokwe. (2016). Scholarship at UWindsor Environmental Literacy Assessment: Assessing the Strength of an Environmental Education Program ( EcoSchools ) in Ontario Secondary Schools for Environmental Literacy Acquisition.

C. Castano. (2008). Res. Sci. Educ. 38(5) pp. 565-587.

C. N. Oktavian and E. Maryani. (2003). Jurnal Pendidikan Geografi 15(2) p.15-30.

Fathil M. (2015) Al-Ta'lim Journal 22(2): 96106.

H. R. Hungerford and T. L. Volk. (2013). The J. of Environ Educ pp.37-41.

J. Lewis, J. Leach. (2006). Int. Journal of Sci. Educ. 28(11) 1267-1287 
K. Supardi Imam. (2017). Pembelajaran Kimia terintegrasi Karakter Religius Semarang: UNNES PRESS

L. Simonneaux and J. Simonneaux. (2009). Cult. Stud. Sci. Educ. 4(3) pp. 657-687

N. Mansour. (2015) Int J. of Sci. Educ. 37(11)1767-1794

R. Marks and I. Eilks. (2009). 4(3): 231-245

R. Mulyana. (2009) Jurnal Tabularasa PPs Unimed 6( 2): 175-180

S. Haryani. (2012). Pembelajaran Praktikum Kimia Analitik Berbasis Masalah. Semarang: UNNES PRESS.

S. Khanafiyah and D. Yulianti. (2013). JPFI 9 pp. $35-42$
S. Ozsoy, H. Ertepinar, and N. Saglam. (2012). Asia-Pacific Forum on Science Learning and Teaching $13 \mathrm{pp} .1-25$.

Siswanto. (2008). Karsa 14(2).

T. D. Sadler and D. L. Zeidler. (2004). Sci. Educ. 88(1): 4-27.

T. D. Sadler and L. A. Donnelly. (2006). Int. J. Sci. Educ. 28(12):1463-1488.

T. L. Milfont and J. Duckitt. (2010). J. of Environ. Psyc. 30 pp. 80-94.

V. Albe. (2008). Res. Sci. Educ. 38(1): 67-90

Z. F. Azizah, P. Karyanto, B. A. Prayitno, and R. R. Sapartini (.....) Proc. Bio Educ. Conf. 14 (1) 415-423. 